\title{
Strategi Pemasaran Tenun Ulap doyo (Daun Lemba) Menggunakan Matriks SWOT (Studi Kasus pada UMKM Pokant Takaq)
}

\section{Marketing Strategy of Ulap doyo (Lemba Leaf) Woven Using SWOT Matrix (Case Study: Pokant Takaq UMKM)}

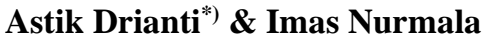 \\ Program Studi Agribisnis, Fakultas Pertanian Universitas Kutai Kartanegara Tenggarong \\ *astikdrianti@unikarta.ac.id
}

\begin{abstract}
ABSTRAK
Kerajinan tenun Ulap Doyo Dayak Benuaq merupakan salah satu ciri khas Kalimantan, khususnya Kalimantan Timur. Pokant Takaq, adalah UMKM yang merupakan gabungan dari beberapa pengrajin tenun ulap doyo yang ada di Kecamatan Tenggarong. Tujuan penelitian ini adalah untuk mengidentifikasi kondisi internal dan eksternal yang mempengaruhi pemasaran hasil tenun ulap doyo dan untuk mengetahui alternatif strategi yang dapat diterapkan dalam pemasaran hasil tenun ulap doyo menggunakan analisis SWOT. Untuk menjawab dua tujuan tersebut maka digunakan analisis SWOT. Penelitian ini dilaksanakan di UKM Pokant Takaq Kecamatan Tenggarong Kabupaten Kutai Kartanegara pada bulan April-Mei 2020. Hasil penelitian memberikan alternatif strategi yang dapat diterapkan yaitu: a. Memanfaatkan surat izin usaha untuk membuka oulet $b$. Mempertahankan kualitas produk untuk memenuhi permintaan pasar ekspor dengan didukung oleh warna dan motif khas. c. Memanfaatkan peran pemerintah dalam promosi serta dukungan model pemasaran yang dinamis. d. Memanfaatkan teknologi informasi dalam promosi tenun ulap doyo. e. Menjaga hubungan baik dengan pemasok bahan baku serta meningkatkan produksi.
\end{abstract}

Kata Kunci: Tenun ulap doyo, lemba, strategi pemasaran, SWOT.

\begin{abstract}
Ulap Doyo Dayak Benuaq weaving is one of the characteristics of Kalimantan, especially East Kalimantan. Pokant Takaq is a UMKM which is a combination of several doyo weaving craftsmen in Tenggarong District. The purpose of this research is to identify internal and external conditions that affect the marketing of doyo weaving products and to find out alternative strategies that can be applied in the marketing of doyo weaving using SWOT analysis. To answer these two objectives, a SWOT analysis is used. This research was conducted at UKM Pokant Takaq, Tenggarong District, Kutai Kartanegara Regency in April-May 2020. The results of this study provide alternative strategies that can be applied, namely: a. Utilizing business permits to open outlets $b$. Maintaining product quality to meet export market demands, supported by distinctive colors and motifs. c. Take advantage of the government's role in the promotion and support of a dynamic marketing model. d. Utilizing information technology in the promotion of doyo weaving. e. Maintain good relationships with suppliers of raw materials and increase production.
\end{abstract}

Keywords: Ulap doyo wovens, lemba, marketing strategy, SWOT.

Article History Submitted: November 19, 2020 Approved with minor revision: December 20, 2020 Accepted: December 20, 2020 Published: December 29, 2020

\section{PENDAHULUAN}

Tenun Ulap doyo atau tenun daun tanaman Lemba merupakan tenun khas, warisan dayak Benuaq dari Kutai Barat. Tenun ini diolah sebagai kain khas yang digunakan pada upacara adat dan kegiatan keagamaan dalam masyarakat dayak
Benuaq. Tenun ulap doyo (daun lemba) saat ini mulai dikembangkan sebagai bagian dari kearifan lokal. Tenun ini memiliki motif khas, dan selama ini pengerjaannya masih manual dan diturunkan dari generasi ke generasi.

Kain tenun ulap doyo, kain ini berasal dari kerajaan tertua di Indonesia 
yaitu Kutai, Kalimantan Timur. Ulap doyo terbuat dari bahan alami yaitu daun doyo yang diolah menjadi benang. Ciri khas kain ini adalah perpaduan motif garis-garis serta corak flora fauna (Anonim, 2019).

Di Kalimantan Timur, serat daun doyo atau lemba digunakan untuk praktik tradisional tenun kain ulap doyo. Permintaan tanaman doyo sebagai bahan baku kain tenun ulap doyo memang tinggi, tetapi ketersediaan bahan baku rendah. Hanya ada beberapa lokasi yang memiliki tanaman doyo dan itupun tidak banyak, yaitu 15 titik lokasi dari 6 kecamatan di Kalimantan Timur (Kecamatan Tenggarong, Kota Bangun, Muara Wis, Anggana, Bongan dan Jempang) (Nugroho, 2018).

Kecamatan Tenggarong merupakan salah satu penghasil tenun ulap doyo (daun lemba) ini. Dan pengrajin tenun ini berpusat pada UKM Pokant Takaq. Yang merupakan gabungan dari beberapa pengrajin tenun ulap doyo. Sebagai warisan budaya tenun ini mulai diperkenalkan oleh pemerintah daerah Kutai Kartanegara, bahkan pada beberapa kegiatan, pemerintah daerah mewajibkan pegawainya menggunkan pakaian dari bahan ulap doyo tersebut. Pemerintah Kabupaten Kutai Barat mewajibkan PNS untuk mengenakan motif ulap doyo (Lestari, 2015). Sehingga dirasa penting untuk mengetahui bagaimana strategi pemasaran dari tenun ulap doyo (daun lemba) ini sehingga bisa semakin berkembang.

Tradisi menenun ulap doyo dibawa dari daerah Tanjung Isuy, Kabupaten Kutai Barat. Pengrajin tenun ulap doyo berkumpul menjadi kelompok pengrajin tenun ulap doyo, anggota kelompok Pokant Takaq berjumlah 35 orang dengan sebaran tempat yang berbeda, seperti di Lapangan Pemuda, Jl. Mangkuraja dan sekitarnya, Jl. Gunung Belah, dan sebagian lagi ada di Tanjung Isuy Kabupaten Kutai Barat.

Menurut penenun ulap doyo, untuk menghasilkan satu kain tenun dengan panjang sekitar $1,5 \mathrm{~m}$, itu membutuhkan sekitar dua gulungan benang. Gulungan benang terbuat dari sekitar tiga puluh senik, dan senik dihasilkan dari 30-36 daun lemba segar. Dengan demikian, membutuhkan 1800-2160 daunlembauntuk menenun satu lembar kain (Raden, 2017).

Tenun ulap doyo merupakan tradisi yang turun temurun dari suku dayak benuaq. Hasil dari tenun ulap doyo bisa di produksi kembali untuk menambah nilai jualnya, seperti membuat pakaian, sepatu, tas, dan sovenir lainnya. Namun untuk bahan pembuatan produk-produk tersebut tidak murni menggunakan tenun ulap doyo, ada yang menambahkan dari kain lainnya agar menjadi produk tersebut. Akan tetapi bahan untuk pembuatan produk bisa sesuai dengan permintaan pelanggan, apakah original dari tenun ulap doyo atau semi ulap doyo.

Definisi strategi pemasaran sebagai alat fundamental yang direncanakan untuk mencapai tujuan perusahaan dengan mengembangkan keunggulan bersaing yang berkesinambungan melalui pasar yang dimasuki dan program pemasaran yang digunakan unutuk melayani pasar sasaran tersebut (Tjiptono, 2008).

Strategi pemasaran pada dasarnya adalah rencana yang menyeluruh, terpadu dan menyatu di bidang pemasaran, yang memeberikan panduan tentang kegiatan yang akan dijalankan agar dapat tercapainya tujuan pemasaran dalam perusahaan. Oleh karena itu penentuan strategi pemasaran harus didasarkan atas analisis lingkungan eksternal dan internal perusahaan melalui analisis keunggulan dan kelemahan perusahaan, serta analisis kesempatan dan ancaman yang dihadapi perusahaan dari lingkungannya (Assauri, 2004).

Menurut Kotler dan Amstrong, strategi pemasaran adalah pendekatan pokok yang akan digunakan oleh unit bisnis dalam mencapai sasaran yang telah ditetapkan lebih dulu, didalamnya tercantum keputusan-keputusan pokok mengenai target pasar, penempatan produk di pasar, bauran pemasaran, dan tingkat biaya pemasaran yang diperlukan (Kotler, 2012).

Rangkuti, menyebutkan bahwa analisis SWOT adalah identifikasi berbagai 
faktor secara sistematis untuk merumuskan strategi perusahaan. Analisis ini didasarkan pada logika yang dapat memaksimalkan kekuatan (Strengths) dan peluang (Opportunities), namun secara bersamaan dapat meminimalkan kelemahan (Weaknesses) dan ancaman (Threats) (Rangkuti, 2000). Penelitian ini menentukan strategi yang dapat diterapkan pada UKM Pokant Takaq. Tujuan penelitian ini adalah untuk mengidentifikasi kondisi internal dan eksternal yang mempengaruhi pemasaran hasil tenun ulap doyo dan untuk mengetahui alternatif strategi yang dapat diterapkan dalam pemasaran hasil tenun ulap doyo menggunakan analisis SWOT

\section{METODE PENELITIAN}

Penelitian ini dilaksanakan di UKM Pokant Takaq Takaq Kecamatan Tenggarong Kabupaten Kutai Kartanegara pada bulan April-Mei 2020, dengan menggunakan analisis SWOT dimana akan diidentifikasi faktor eksternal dan faktor internal. Untuk itu diperlukan Informan Kunci. Ketua Kelompok Pokant Takaq, 1 pengrajin ulap doyo, 1 Reseller ulap doyo, 1 orang konsumen ulap doyo dan 1 orang dari dinas Perindutrian dan Perdagangan, adalah informan kunci dalam penelitian ini.
Matriks SWOT adalah alat yang dapat dipakai untuk menyusun faktorfaktor strategis perusahaan. Matriks ini dapat menggambarkan secara jelas bagaimana peluang dan ancaman eksternal yang dihadapi perusahaan dapat disesuaikan dengan kekuatan dan kelemahan yang dimilikinya (Rangkuti, 2000). Matriks ini dapat menghasilkan empat set kemungkinan alternatif strataegi.

1. Strategi SO

Strategi ini dibuat berdasarkan jalan pikir perusahaan yaitu dengan memanfaatkan seluruh kekuatan untuk merebut dan memanfaatkan peluang sebesar-besarnya.

2. Strategi ST

Strategi ini digunakan dengan menggunakan kekuatan yang dimiliki perusahaan untuk mengatasi ancaman.

3. Strategi WO

Strategi ini pemanfaatan peluang yang ada untuk meminimalkan kelemahan yang ada.

4. Strategi WT

Strategi ini didasarkan pada kegiatan yang bersifat defensif dan berusaha meminimalkan kelemahannya yang ada serta menghindari ancaman.

Strategi SWOT seperti yang diuraikan di atas secara rinci dapat digambarkan dalam matriks SWOT seperti di bawah ini :

\begin{tabular}{|c|c|c|}
\hline IFAS & $\begin{array}{l}\text { STREGHTS (S) } \\
\text { - Tentukan 5-10 faktor } \\
\text { kekuatan internal }\end{array}$ & $\begin{array}{l}\text { WEAKNESSES (W) } \\
\text { Tentukan 5-10 faktor } \\
\text { kelemahan }\end{array}$ \\
\hline $\begin{array}{l}\text { OPPORTUNITIES } \\
\qquad \begin{array}{l}\text { (O) } \\
\text { - Tentukan 5-10 } \\
\text { faktor peluang } \\
\text { eksternal }\end{array} \\
\end{array}$ & $\begin{array}{l}\text { STRATEGI SO } \\
\text { - Ciptakan strategi yang } \\
\text { menggunakan kekuatan } \\
\text { untuk memanfaatkan } \\
\text { peluang }\end{array}$ & $\begin{array}{l}\text { STRATEGI WO } \\
\text { - Ciptakan strategi yang } \\
\text { meminimalkan } \\
\text { kelemahan untuk } \\
\text { menfaatkan peluang }\end{array}$ \\
\hline $\begin{array}{l}\text { TREATHS (T) } \\
\text { - Tentukan 5-10 } \\
\text { faktor ancaman } \\
\text { eksternal }\end{array}$ & $\begin{array}{l}\text { STRATEGI ST } \\
\text { - } \text { Ciptakan strategi yang } \\
\text { menggunakan kekuatan } \\
\text { untuk mengatasi } \\
\text { ancaman }\end{array}$ & $\begin{array}{l}\text { STRATEGI WT } \\
\text { - } \text { Ciptakan strategi yang } \\
\text { meminimalkan } \\
\text { kelemahan dan } \\
\text { menghindari ancaman }\end{array}$ \\
\hline
\end{tabular}

Gambar 2: Matriks SWOT (Rangkuti, 2000) 


\section{Tahap Pengumpulan Data Informan Kunci}

1. Analisisfaktor lingkungan internal (IFAS) dimana variabel kekuatan dan kelemahan terdiri dari 6 indikator kekuatan dan 5 indikator kelemahan yang terdapat pada usaha kerajinan hasil tenun ulap doyodengan menerapkan bauran pemasaran 4P (Product, Price, Place, Promotion) sebagai berikut:

a. Kekuatan (Strength)

(S1) Telah memiliki surat izin usaha

(S2) Kios milik sendiri

(S3) Memiliki warna dan motif yang khas

(S4) Handmade nilai seni dengan buatan tangan

(S5) Kualitas produk yang bagus

(S6) Adanya modal usaha yang kuat

b. Kelemahan (Weaknesses)

(W1)Harga yang cenderung mahal

(W2) SDM yang relatif rendah dalam produksi tenun

(W3) Produk tidak dapat diproduksi masal

(W4) Tidak ada pembuatan brosur untuk promosi

(W5) Tidak dilakukan promosi secara rutin

2. Analisis faktor lingkungan ekternal (EFAS) dimana variabel peluang dan ancaman terdiri dari 7 indikator peluang dan 5 indikator ancaman yang terdapat pada usaha kerajinan hasil tenun ulap doyo dengan menerapkan bauran pemasaran 4P (Product, Price, Place, Promotion)

a. Peluang (Opportunies)

(O1) Penambahan outlet di tempat lain

(O2) Adanya hubungan yang baik dengan pemasok bahan baku

(O3) Terbukanya pasar ekspor

(O4) Perubahan gaya hidup masyarakat

(O5) Model pemasaran yang semakin dinamis

(O6) Peran pemerintah dalam promosi tenun doyo cukup tinggi

(O7) Tersedianya teknologi informasi untuk promosi b. Ancaman (Threats)

(T1) Banyaknya kain modern di kalangan masyarakat

(T2) Kurangnya ketertarikan masyarakat dengan produk lokal

(T3) Adanya hasil tenun dari luar daerah yang lebih murah

(T4) Langkanya bahan baku

(T5) Selera masyarakat yang berbeda dalam fashion.

\section{HASIL DAN PEMBAHASAN}

\section{Hasil}

\section{Analisis Lingkungan Internal}

Analisis lingkungan internal digunakan untuk mengidentifikasi lingkungan internal pada Usaha Hasil Tenun Ulap doyoPokant Takaq untuk mengetahui faktor-faktor yang menjadi kekuatan dan kelemahan. Lingkungan internal meliputi Manajemen, keuangan, produksi, sumber daya manusia, pemasaran.

\section{Manajemen}

Manajemen di Usaha Pengrajin Tenun Ulap doyo Pokant Takaq masih sederhana, yaitu membentuk struktur organisasi yang terdiri dari Ketua kelompok, Sekretaris dan Bendahara. Manajemen dibentuk untuk mengelola usaha agar usaha tetap berjalan, terutama pengelolaan dalam modal yang akan dikeluarkan.

\section{Keuangan}

Modal usaha sangatlah diperlukan dalam membangun sebuah kegiatan usaha. Oleh karena itu diperlukan sejumlah dana sebagai dasar ukuran finansial untuk usaha yang akan dijalankan. Sumber modal usaha dapat diperoleh dari modal sendiri, bantuan Pemerintah, lembaga keuanagan baik bank ataupun non bank. Besar kecilnya modal akan mempengaruhi perkembangan usaha dalam mencapai produksi dan pendapatan. Modal awal Rp 1.000.000,- yang digunakan untuk membeli hasil tenun dari pengrajin karena pada saat awal mengembangkan usaha, harga ulap doyo masih sekitar Rp 150.000,-/ lembar dan 
merupakan modal milik sendiri untuk usaha hasil tenun ulap doyo. Hingga saat ini modal modal dikelola dengan baik sehingga hasil penjualan dapat selalu digunakan kembali dan bertambah.

\section{Sumber Daya Manusia}

Sumberdaya yang dimaksud dalam usaha hasil tenun ulap doyo adalah pengrajin-pengrajin tenun yang ada di Kecamatan Tenggarong ataupun di luar Tenggarong, peran Pengrajin dalam kelompok usaha kerajinan ini yaitu sebagai pemasok yang terdiri dari pemasok bahan baku ataupun produk yang sudah jadi, sehingga jika saat ada pesanan yang tibatiba dapat membeli dipengrajin yang telah menyelesaikan hasil tenun ulap doyo. SDM dalam produksi hasil tenun ulap doyo rendah karena generasi untuk menenun dan yang membuat alat tenun semakin berkurang. Selain pengrajin tenun, reseller termasuk juga dalam sumber daya manusia dalam usaha hasil tenun ulap doyo, karena Reseller membantu dalam pemasaran hasil tenun ulap doyo.

\section{Produksi}

Proses produksi tenun ulap doyo yaitu dengan memilih daun doyo yang sempurna, tidak terlalu tua atau terlalu muda. Kemudian daun dibawa ke sungai atau tempat air kemudian daun tersebut dikerik (lorot) untuk mendapatkan serat daun doyo. Serat daun doyo kemudian di jemur hingga kering dan kemudian disambung atau dipintal, setelah dipintal lanjut di susun atau dihani. Jika tidak berniat untuk membuat motif atau warna bisa langsung di tenun, tetapi jika menginginkan warna dan motif, serat diikat dan disusun ke telegan untuk dimotif kemudian diwarnai menggunakan pewarna sintetis ataupun alam dan kemudian dijemur minimal 5 hari. Setelah penjemuran serat yang telah disusun tadi di buka kembali dan dihani lagi untuk kombinasi dengan benang lainnya. Kemudian di cucuk di gigi tenun dan langsung ditenun. Untuk menyelesaikan satu lembar ulap doyo membutuhkan waktu maksimal 7 hari untuk yang bermotif dan berwarna.

Bahan baku untuk menenun ulap doyo adalah serat daun doyo. Selama ini untuk mendapatkan bahan baku tenun masih dari Kutai barat dan ada yang dari Muara Leka. Untuk menghasilkan 1 lembar kain membutuhkan 2 gulung benang, gulungan benang terbuat dari sekitar 30 senik, senik dihasilkan dari 30 36 daun doyo segar. Dengan demikian untuk 1 lembar kain doyo membutuhkan 1.800-2.160 lembar daun doyo segar (Nugroho, 2018). Alat untuk produksi jelas sederhana dengan alat tenun yang dapat dibuat sendiri ataupun memesan pada seseorang yang dapat membuat alat tenun.

\section{Pemasaran}

Pemasaran perlu mendapat perhatian serius oleh UMKM. Terutama didalam proses penetapan strategi pemasaran harus benar-benar matang, sehingga strategi pemasaran yang dipilih akan mampu menembus pasar. Apalagi kondisi persaingan yang semakin ketat seperti saat ini, kemampuan untuk merebut pangsa pasar akan mempengaruhi kelangsungan hidup UMKM itu sendiri (Wibowo, 2015).

Pemasaran dilakukan dengan menggunakan media sosial seperti instagram, dan memiliki Web serta selalu mengikuti setiap ada event, namun promosi melalui sosial media tidak dilakukan secara rutin. Usaha tenun juga memiliki reseller agar lebih membantu dalam memasarkan produk. Reseller sendiri ada di beberapa tempat, seperti Kubar, Samarinda, Balik Papan dan Jakarta.

Harga kain yang sudah jadi Rp 200.000,-/lembar untuk ulap doyo tanpa motif dan warna dan untuk ulap doyo yang bermotif dan berwarna Rp 600.000,/lembar. Selama ini pelanggan yang telah membeli kain ulap doyo banyak dari luar negeri dan luar daerah Kalimantan. Selama usaha berjalan belum ada pencatatan pembelanjaan hanya mencatat penjualan saja dan penjualan selama ini tidak menurun ataupun meningkat. 


\section{Analisis Lingkungan Eksternal}

Analisis lingkungan ekternal untuk mengidentifikasi lingkungan eksternal pada usaha hasil tenun ulap doyo Pokant Takaq untuk mengetahui faktor-faktor yang menjadi peluang dan ancaman pada usaha hasil tenun ulap doyo Pokant Takaq. Lingkungan eksternal meliputi Pemerintah, konsumen, pesaing dan teknologi informasi.

\section{Pemerintah}

Dalam usaha hasil tenun ulap doyo Pemerintah sangat mendukung, terutama pada pemasaran hasil tenun. Setiap event yang diadakan oleh pemerintah selalu ada tempat yang tersedia untuk hasil tenun ulap doyo untuk mengenalkan serta mempromosikan produk. Bahkan pada awal usaha tenun ulap doyo diangkat kembali, Dinas Perindustrian dan Perdagangan yang membawa hasil tenun ulap doyo beserta ketua kelompok dan keluarga ke luar daerah Kalimantan untuk mengenalkan dan mempromosikan hasil tenun ulap doyo tersebut. Dengan adanya peran pemerintah dalam promosi saat ini hasil tenun ulap doyo telah dikenal hingga ke luar Negeri, sehingga pemerintah dapat membuka pasar ekspor untuk penjualan ke luar Negeri.Selain itu pemerintah mewajibkan kementerian dan lembaga belanja produk di UMKM dengan pagu minimal 40 persen. Kebijakan ini untuk mendorong sektor UMKM dapat tumbuh. UMKM menjadi mayoritas sektor usaha dengan rasio 99 persen dengan serapan tenaga kerja 97 persen (Kementrian Koperasi dan Usaha Kecil dan Menengah Republik Indonesia, 2020).

\section{Konsumen}

Usaha hasil tenun ulap doyo Pokant Takaq memberikan produk dan pelayanan terbaik untuk untuk konsumennya. Jika konsumen memiliki keluhan dengan produk yang diterima dapat langsung menghubungi seseorang yang bersangkutan saat pemesanan produk melalui online, seperti jika produk cacat karna kesalahan saat pengemasan dapat diganti. Kemudian ketika konsumen membeli lebih dari 1 item produk atau dalam jumlah banyak akan memberikan keringan saat pengiriman produk, yaitu ongkir ditanggung oleh pengirim.

\section{Pesaing}

Pesaing di era industri yang semakin berkembang kini sangat banyak. Dalam usaha hasil tenun ulap doyo sendiri pastinya banyak hasil tenun dari daerah lain, namun semua itu tidak menyusutkan semangat pengrajin usaha tenun ulap doyo dalam memproduksi tenunannya. Karena pengrajin sendiri percaya akan keunikan dari tenun ulap doyo yang tidak akan pernah tersaingi. Namun terkadang selera dan kurangnya ketertarikan masyarakatlah yang menjadi masalah dalam pemasasran.

\section{Teknologi informasi}

Pemanfaatan Teknologi Informasi dalam menjalankan bisnis sering dikenal dengan istilah e-commerce bagi pengusaha kecil dapat memberikan fleksibilitas dalam produksi, memungkinkan pengiriman ke pelanggan secara lebih cepat untuk produk lunak, mengirimkan dan menerima penawaran secara cepat dan hemat, serta mendukung transaksi cepat tanpa kertas (Ramadhani, 2013)

Teknologi informasi semakin berkembang bersamaan perubahan waktu, dengan adanya teknologi saat ini pengrajin hasil tenun ulap doyo memanfaatkan salah satu teknologi informasi untuk memasarkan produknya, selain memasarkan konsumen juga tidak perlu jauh-jauh untuk mendatangi kios untuk memilih produk hasil tenun serta dapat membayar dan mengirim dari jarak yang jauh. Namun untuk produksi hasil tenun ulap doyo sendiri tidak dapat diproduksi masal, karena terkendala dengan bahan baku yang terbatas serta tidak dapat ditenun dengan mesin yang canggih, karena dapat merusak serat yang akan ditenun.

\section{Perumusan Strategi}

Hasil analisis faktor internal dan eksternal dapat dilihat pada tabel berikut ini. 
Tabel 1. Matrik faktor strategi internal

\begin{tabular}{|c|c|c|c|c|}
\hline No. & Faktor-Faktor Internal & $\begin{array}{c}\text { Bobot Rata- } \\
\text { rata }\end{array}$ & $\begin{array}{c}\text { Rating } \\
\text { Rata-rata }\end{array}$ & $\begin{array}{c}\text { Nilai } \\
\text { Tertimbang }\end{array}$ \\
\hline \multicolumn{5}{|c|}{ Kekuatan } \\
\hline 1 & Telah memiliki surat izin usaha & 0,124 & 3,2 & 0,397 \\
\hline 2 & Kios milik sendiri & 0,100 & 3,2 & 0,320 \\
\hline 3 & Memiliki warna dan motif yang khas & 0,124 & 3,8 & 0,471 \\
\hline 4 & Handmade nilai seni dengan buatan tangan & 0,130 & 3,6 & 0,468 \\
\hline 5 & Kualitas produk yang bagus & 0,106 & 3,8 & 0,403 \\
\hline 6 & Adanya modal usaha yang kuat & 0,088 & 3,2 & 0,282 \\
\hline & Sub Total & 0,672 & & 2,3404 \\
\hline \multicolumn{5}{|c|}{ Kelemahan } \\
\hline 7 & Harga yang cenderung mahal & 0,052 & 1,6 & 0,083 \\
\hline 8 & SDM yang relatif rendah dalam produksi tenun & 0,088 & 2 & 0,176 \\
\hline 9 & Produk tidak dapat diproduksi masal & 0,074 & 2,6 & 0,192 \\
\hline 10 & Tidak ada pembuatan brosur untuk promosi & 0,046 & 2,4 & 0,110 \\
\hline \multirow[t]{3}{*}{11} & Tidak dilakukan promosi secara rutin & 0,068 & 2,4 & 0,163 \\
\hline & Sub Total & 0,328 & & 0,7252 \\
\hline & Total & 1 & 31,8 & 3,0656 \\
\hline
\end{tabular}

Sumber: Data Primer diolah, (2020)

Tabel 2. Matriks faktor strategi eksternal

\begin{tabular}{|c|c|c|c|c|}
\hline No. & Faktor-Faktor Eksternal & $\begin{array}{c}\text { Bobot } \\
\text { Rata- } \\
\text { rata }\end{array}$ & $\begin{array}{c}\text { Rating } \\
\text { Rata- } \\
\text { rata }\end{array}$ & $\begin{array}{c}\text { Nilai } \\
\text { Tertimbang }\end{array}$ \\
\hline & \multicolumn{4}{|l|}{ Peluang } \\
\hline 1 & Penambahan outlet di tempat lain & 0,082 & 2,8 & 0,230 \\
\hline \multirow[t]{2}{*}{2} & Adanya hubungan yang baik dengan pemasok & 0,108 & 3,6 & 0,389 \\
\hline & bahan baku & 0,108 & 3,4 & 0,367 \\
\hline 3 & Terbukanya pasar ekspor & 0,052 & 2,4 & 0,125 \\
\hline 4 & Perubahan gaya hidup masyarakat & 0,088 & 3,2 & 0,282 \\
\hline 5 & Model pemasaran yang semakin dinamis & 0,114 & 3,6 & 0,410 \\
\hline 6 & $\begin{array}{l}\text { Peran pemerintah dalam promosi tenun doyo } \\
\text { cukup tinggi }\end{array}$ & 0,102 & 3,4 & 0,347 \\
\hline \multirow[t]{3}{*}{7} & Tersedianya teknologi informasi untuk promosi & & & \\
\hline & Sub Total & 0,654 & & 2,1492 \\
\hline & \multicolumn{4}{|l|}{ Ancaman } \\
\hline 8 & Banyaknya kain modern di kalangan masyarakat & 0,054 & 2,2 & 0,119 \\
\hline 9 & $\begin{array}{l}\text { Kurangnya ketertarikan masyarakatdengan produk } \\
\text { lokal }\end{array}$ & 0,06 & 2 & 0,120 \\
\hline 10 & Adanya hasil tenun dari luar daerah yang lebih & 0,052 & 2 & 0,104 \\
\hline 11 & murah & 0,114 & 2,2 & 0,251 \\
\hline \multirow[t]{4}{*}{12} & Langkanya bahan baku & 0,066 & 3 & 0,198 \\
\hline & Selera masyarakat yang berbeda dalam fashion & & & \\
\hline & Sub Total & 0,346 & & 0,7916 \\
\hline & Total & 1 & 30,4 & 2,9408 \\
\hline
\end{tabular}

Sumber: Data Primer diolah, (2020) 


\section{Diagram SWOT}



Gambar 1. Diagram SWOT strategi pemasaran usaha hasil tenun ulap doyo di Kecamatan Tenggarong Kabupaten Kutai Kartanegara, 2020.

\section{Pembahasan}

Berdasarkan hasil analisis maka strategi yang bisa diterapkan pada UKM Pokant Takaq adalah Strategi SO, yaitu merupakan strategi yang mengoptimalkan kekuatan untuk mengambil peluang yang besar. Strategi pemasaran hasil tenun ulap doyo memanfaatkan seluruh kekuatan untuk merebut dan memanfaatkan peluang yang ada. Strategi yang harus diterapkan dalam kondisi ini adalah mendukung strategi agresif, diantaranya adalah:

a. Memanfaatkan surat izin usaha untuk penambahan oulet ditempat lain. Berdasarkan hasil wawancara dengan ketua kelompok tenun ulap doyo, usaha kerajinan tenun ulap doyo berencana untuk menambah outlet di tempat lain agar memudahkan konsumen dalam mendapatkan produk.

b. Mempertahankan kualitas produk untuk memenuhi permintaan pasar ekspor dengan warna dan motif yang khas. Berdasarkan hasil wawancara dengan informan, dinyatakan bahwa hasil tenun ulap doyo yang diproduksi telah memasuki pasar ekspor. Karena itu pengrajin berusaha semaksimal mungkin untuk mempertahankan kualitas produk.

c. Memanfaatkan peran pemerintah dalam promosi. Berdasarkan wawancara dengan informan, warna dan motif yang khas dari tenun ulap doyo mendapatkan perhatian dari pemerintah dalam 
promosi karena merupakan salah satu nilai budaya bagi daerah Kalimantan Timur.

d. Memanfaatkan teknologi informasidalam promosi tenun ulap doyo. Usahatenun ulap doyo dapat memanfaatkanteknologi informasi yang ada, seperti membayar media cetak ataupun teknologi informasi internet dalam mempromosikan hasil tenun ulap doyo agar lebih dikenal masyarakat.

e. Menjaga hubungan yang baik dengan pemasok untuk meningkatkan produksi dengan memanfaatkan ketersedian kios. Tujuannya adalah hubungan yang terjalin dengan pemasok harus tetap baik agar selalu tetap produksi dan pengrajin lainpun tidak bingung akan dijual kemana hasil produksi mereka, karena telah memiliki kios untuk menampung hasil produksi.

1. Strategi ST, yaitu merupakan situasi strategi yang menggunakan kekuatan untuk mengatasi ancaman. Usaha tenun ulap doyo menghadapi berbagai ancaman namun masih memiliki kekuatan untuk mengatasi ancaman tersebut. Strategi yang harus diterapkan dalam kondisi ini adalah menggunakan kekuatan dari dalam untuk mengatasi ancaman dari luar dengan cara mendukung strategi diversifikasi.

a. Menjaga kualitas serta motif yang khas untuk menarik minat masyarakat. Minat masyarakat terhadap hasil tenun ulap doyo terbilang rendah, salah satu strategi yang dapat dilakukan oleh pengrajin adalah tetap menjaga kualitas dan motif yang sudah menjadi ciri khas tenun ulap doyo tersebut.

b. Mengoptimalkan modal untuk mengatasi langkanya bahan baku. Selama berjalannya usaha hasil tenun ulap doyo selalu terkendala dengan bahan baku, sehingga salah satu strategi yang dapat dijalankan yaitu dengan melakukan kerjasama berupa pembinaan kepada mitra pemasok bahan baku dalam rangka domestikasi dan pengembangan budidaya tanaman doyo (lemba). c. Memanfaatkan warna dan motif yang khas untuk mengantisipasi tenun dari luar daerah. Dengan adanya warna dan motif yang khas pada ulap doyo diharapkan tidak akan kalah saing dengan hasil tenun dari luar daerah, karena setiap daerah memiliki ciri khas masing-masing.

2. Strategi WO, dalam situasi ini pemasaran hasil tenun ulap doyo memiliki peluang, tetatpi juga memiliki beberapa kendala/kelemahan internal. Dalam situasi ini strategi difokuskan untuk meminimalkan kelemahankelemahan internal dan dapat merebut peluang yang ada.

a. Meningkatkan kualitas SDM dalam produksi tenun yang didukung oleh peran pemerintah. Sumberdaya manusia dinyatakan kurang dalam tingkat keterampilan pada proses produksi tenun ulap doyo. Selain itu, kurangnya minat generasi muda terhadap tenun ulap doyo juga membuat regenerasi pengrajin menjadi kendala. Insentif pemerintah akan menjadi pendukung dalam industri ini, bisa berupa pelatihan dan pengenalan tenun ataupun hal lain.

b. Memanfaatkan teknologi informasi untuk melakukan promosi secara rutin, termasuk brosur. Selama berjalannya usaha kerajinan tenun ulap doyo sampai saat ini tidak tersedia brosur untuk kegiatan promosi, padahal kemajuan teknologi informasi pada saat ini dapat membantu untuk membuat brosur dengan desain yang menarik untuk melakukan promosi.

c. Memanfaatkan peran pemerintah dalam promosi hasil tenun ulap doyo. peran pemerintah dalam promosi hasil tenun ulap doyo sampai saat ini masih membantu, karena setiap ada event pemerintah selalu menyediakan tempat untuk para pengrajin termasuk pengrajin ulap doyo untuk berpartisipasi dalam expo.

3. Strategi WT, kondisi ini merupakan situasi yang tidak menguntungkan dalam pemasaran hasil tenun ulap doyo, 
selain memiliki kelemahan internal usaha tenun juga memiliki ancaman yang berasal dari luar.

a. Melakukan promosi hasil tenun ulap doyo untuk menarik minat masyarakat. Salah satu strategi untuk menarik minat masyarakat yaitu dengan diadakannya promosi, promosi yang dilakukan yaitu menggunakan media sosial ataupun brosur sebagai salah satu media promosi. b. Meningkatkan SDM dalam produksi tenun untuk mengantisipasi banyaknya kain modern di kalangan masyarakat dan hasil tenun dari luar daerah. Tujuannya adalah untuk selalu memproduksi tenunan agar tidak kalah dengan kain modern ataupun hasil tenun dari luar. Dengan motif hasil yang khas akan menjadi nilai tersendiri bagi ulap doyo.

\section{Tabel 12. Matrik SWOT}

\begin{tabular}{|c|c|c|}
\hline EFAS & $\begin{array}{l}\text { STREGHTS(S) } \\
\text { 1. Telah memiliki surat izin usaha } \\
\text { 2. Kios milik sendiri } \\
\text { 3. Memiliki warna dan motif yang } \\
\text { khas } \\
\text { 4. Handmade nilai seni dengan buatan } \\
\text { tangan } \\
\text { 5. Kualitas produk yang bagus } \\
\text { 6. }\end{array}$ & $\begin{array}{l}\text { WEAKNESSES }(\mathbf{W}) \\
\text { 1. Harga yang cenderung mahal } \\
\text { 2. SDM yang relatif rendah dalam } \\
\text { produksi tenun } \\
\text { 3. Produk tidak dapat diproduksi } \\
\text { masal } \\
\text { 4. Tidak ada pembuatan brosur } \\
\text { untuk promosi } \\
\text { 5. Tidak dilakukan promosi secara } \\
\text { rutin }\end{array}$ \\
\hline $\begin{array}{l}\text { OPPORTUNIES (O) } \\
\text { 1. Penambahan outlet di } \\
\text { tempat lain } \\
\text { 2. Adanya hubungan yang } \\
\text { baik dengan pemasok } \\
\text { bahan baku } \\
\text { 3. Terbukanya pasar ekspor } \\
\text { 4. Perubahan gaya hidup } \\
\text { masyarakat } \\
\text { 5. Model pemasaran yang } \\
\text { semakin dinamis } \\
\text { 6. Peran pemerintah dalam } \\
\text { promosi tenun doyo cukup } \\
\text { tinggi } \\
\text { 7. Tersedianya teknologi } \\
\text { informasi untuk promosi }\end{array}$ & \begin{tabular}{|l}
\multicolumn{1}{c}{ STRATEGI SO } \\
1. \\
Memanfaatkan surat izin usaha \\
untuk membuka oulet ditempat lain \\
(S1), (O1), (S6) \\
2. $\begin{array}{l}\text { Mempertahankan kualitas produk } \\
\text { untuk memenuhi permintaan pasar }\end{array}$ \\
ekspor yang didukung dengan \\
adanya model pemasaran yang \\
dinamis (S5), (O3),(O5), (S3), (S4) \\
3. Memanfaatkan peran pemerintah \\
dalam promosi yang didukung oleh \\
warna dan motif yang khas (O6), \\
(S6), (O5) \\
4. Memanfaatkan teknologi informasi \\
dalam promosi tenun ulap doyo \\
dengan menggunakan modal usaha \\
yang kuat (O7), (S6) \\
Menjaga hubungan yang baik \\
dengan pemasok untuk \\
meningkatkan produksi dengan \\
memanfaatkan ketersedian kios \\
(O2), (S2)
\end{tabular} & \begin{tabular}{l}
\multicolumn{1}{c}{ STRATEGI WO } \\
1. Meningkatkan kualitas SDM \\
dalam produksi tenun yang \\
didukung oleh peran pemerintah \\
(W2), (O6) \\
2. Memanfaatkan teknologi \\
informasi untuk pembuatan \\
brosur agar dapat melakukan \\
promosi secara rutin (O7), (W4), \\
(W5),(O5) \\
3. Memanfaatkan peran pemerintah \\
dalam promosi hasil tenun ulap \\
doyo (O6), (W5)
\end{tabular} \\
\hline \begin{tabular}{ll}
\multicolumn{1}{c}{ TREATHS $(\mathbf{T})$} \\
1. \\
Banyaknya kain modern \\
di kalangan masyarakat \\
2. Kurangnya ketertarikan \\
masyarakatdengan produk \\
lokal \\
3. Adanya hasil tenun dari \\
luar daerah yang lebih \\
murah \\
4. Langkanya bahan baku \\
5. Selera masyarakat yang \\
berbeda dalam fashion
\end{tabular} & 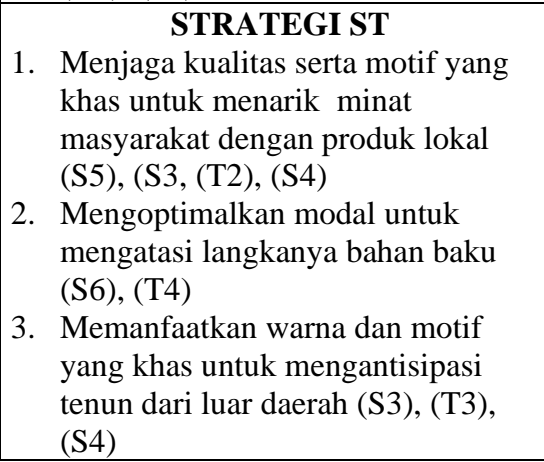 & \begin{tabular}{l}
\multicolumn{1}{c}{ STRATEGI WT } \\
1. Melakukan promosi hasil tenun \\
ulap doyo untuk menarik minat \\
masyarakat (W5), (T2) \\
2. Meningkatkan kualitas SDM \\
dalam produksi untuk \\
mengantisipasi banyaknya kain \\
modern di kalangan masyarakat \\
dan hasil tenun dari luar daerah \\
(W2), (T1), (T3)
\end{tabular} \\
\hline
\end{tabular}

Sumber: Data Primer diolah, (2020) 
Alternatif strategi pemasaran hasil tenun ulap doyo yang berada pada kuadran I yaitu mendukung strategi agresif atau strategi S - O (Strengths - Opportunies). Strategi ini dilakukan dengan menggunakan seluruh kekuatan untuk merebut dan memanfaatkan peluang sebesar-besarnya. Alternatif strategi $\mathrm{S}-\mathrm{O}$ terdiri dari:

1. Memanfaatkan surat izin usaha untuk membuka outlet ditempat lain.

2. Mempertahankan kualitas produk untuk memenuhi permintaan pasar ekspor dengandidukung oleh warna dan motif khas.

3. Memanfaatkan peran pemerintah dalam promosi serta dukungan model pemasaran yang dinamis.

4. Memanfaatkan teknologi informasi dalam promosi tenun ulap doyo.

5. Menjaga hubungan baik dengan pemasok bahan baku serta meningkatkan produksi.

Hasil penelitian lain menggunakan analisis SWOT berkesimpulan bahwa mempertahankan kualitas dan pelayanan produk untuk menarik konsumen, serta memanfaatkan teknologi informasi untuk pemasaran merupakan bagian dari strategi IE yang memanfaatkan kekuatan dan peluang yang ada, dalam hal ini memanfaatkan citra perusahaan serta kualitas (Setyorini, 2016).

\section{KESIMPULAN}

1. Faktor Internal (Kekuatan dan Kelemahan)

Indikator kekuatan yang berpengaruh dalam pemasaran hasil tenun ulap doyo yaitu memiliki warna dan motif yang khas. Sedangkan indikator kelemahan yang berpengaruh adalah tidak dapat diproduksi masal.

2. Faktor Eksternal (Peluang dan Ancaman)

Indikator peluang yang berpengaruh dalam pemasaran hasil tenun ulap doyo yaitu peran pemerintah dalam promosi tenun doyo cukup tinggi. Sedangkan indikator ancaman yang berpengaruh adalah langkanya bahan baku.
3. Memanfaatkan kekuatan serta peluang untuk kemajuan usaha terutama dukungan dana yang besar.

\section{DAFTAR PUSTAKA}

Anonim. (2019, Januari 01). 13 Kain Tradisional Khas Indonesia yang Luar Biasa Indah, Sudah Punya? Dipetik Oktober 30, 2020, dari IDNTimes: http://identimes. com.

Assauri, S. (2004). Manajemen Pemasaran

Dasar, Konsep dan Strategi. Jakarta: Raja Grafindo Persada.

Kementrian Koperasi dan Usaha Kecil dan Menengah Republik Indonesia. (2020, 10 22). Pemerintah

Wajibkan Kementrian dan

Lembaga Belanja Produk di UMKM dengan Minimal

Pagu 40 persen. Dipetik 10 30, 2020, dari Kementrian Koperasi dan Usaha Kecil dan Menengah RepublikIndonesia: http://depkop. go.id.

Kotler, P. d. (2012). Prinsip-prinsip Pemasaran. Jakarta: Penerbit Erlangga.

Lestari, S. (2015). BBC.com. Dipetik November 25, 2020, dari BBC News Indonesia: http://bbc.com.

Nugroho, C. C. (2018). Pertumbuhan Awal Aksesi Doyo Hasil Domestikasi. Magrobis, 18(2) 31-41.

Raden, I. N. (2017). Identification and characterization of Lemba (Curculigo latifolia) in East Kalimantan, Indonesia. Journal of Biological Diversity, 18(4), 13671376.

Ramadhani, F. D. (2013). Optimalisasi Pemanfaatan Teknologi Informasi 
Komunikasi Berbasis Ecommerce sebagai Media Pemasaran Usaha Kecil Menengah Guna Meningkatkan Daya Saing dalam Menghadapi Masyarakat Ekonomi ASEAN 2015.

Economics Development Analisys, 2(2), 135-139.

Rangkuti, F. (2000). Analisis SWOT Teknik Membedah Kasus Bisnis. Jakarta: Gramedia Pustaka Utama.

Rochyat, I. G. (2018). Penambahan Fungsi Pada Kursi Anak Berbahan Rotan sebagai Pengembangan Mebel pada Industri Kreatif. Inosains, 13(1), 61-68 .

Setyorini, H. E. (2016). Analisis Strategi Pemasaran Menggunakan Matriks SWOT dan QSPM (Studi Kasus: Restoran WS Soekarno Hatta Malang). Industria: Jurnal Teknologi dan Manajemen Agroindustri, 5(1) , 46-53.

Tjiptono, F. (2008). Strategi Pemasaran. Yogyakarta: CV. Andi Offset.

Wibowo, D. H. (2015). Analisis Strategi Pemasaran Untuk Meningkatkan Daya Saing UMKM (Studi pada Batik Diajeng Solo). Jurnal Administrasi Bisnis (JAB), 29(1), 59-66. 